\title{
UM CONCEITO DE CIDADANIA PARA SE TRABALHAR A CIDADE
}

\author{
MÁRcio Piñon DE OliveIRA \\ Universidade Federal Fluminense
}

A política surge no entre-os-homens; portanto, totalmente fora dos homens.

Por conseguinte, não existe nenhuma substância política original. A política surge no intra-espaço e se estabelece como relação. (Hannah Arendt)

Como tratar a cidadania numa pesquisa em geografia, tema tão complexo e, até recentemente, de rara abordagem em nossa disciplina? Como operar com este conceito ao nível da escala territorial de uma cidade?

Embora a história do conceito e a trilha que estabelecemos através dos clássicos da ciência política parecesse, a princípio, nos afastar da geografia, logo perceberíamos, na obra A Política, de Aristóteles que, se o conceito de cidadania estava distante de nós enquanto ferramenta (ou veio temático) na pesquisa geográfica, sua geograficidade está no próprio nascimento da polis, ou seja, no nexo político que vincula a cidade, seus habitantes e o seu território, ao Estado ou sociedade política.

Ao longo da história do conceito, por mais que sua noção tenha se ampliado e ganho um sentido abstrato e múltiplo, afastando-se da escala territorial da cidade, é neste espaço, delimitado politicamente, e na rede de lugares que o compõem, que a cidadania deixa de ser um em si e assume a sua dimensão mais concreta e cotidiana. É nas cidades e nos seus lugares, mais especificamente, que os direitos, sob a forma de leis, aparecem de forma palpável e contraditória, decodificando-se em normas e posturas que regem a vida urbana. 
Outro aspecto da geograficidade do conceito, importante a ressaltar, é o de sua escalaridade. A depender do país, da província ou região, da cidade, ou mesmo do bairro em que se mora, a cidadania assume, bem como entre as classes ou grupos sociais, graus diferenciados de existência. Assim, não é absurdo afirmar que somos mais ou menos cidadãos de acordo com o espaço em que estejamos inseridos. Os direitos civis, políticos e sociais passam necessariamente por uma mediação da geograficidade, isto é, dos atributos do espaço (instalações, infra-estruturas, redes etc.) ou dos seus "fixos sociais" (SANTOS, 1987: 43), numa relação na qual as determinações de diferentes escalas geográficas podem se superpor.

O conceito de cidadania guarda, assim, uma concretude que possui íntima relação com a cidade enquanto realidade histórica. Por isso, do ponto de vista de nossa análise, a cidadania só poderia ser entendida enquanto uma prática historicamente construída, delimitada por um poder de Estado que busca estabelecer os contornos de suas possibilidades de realização. Desse modo, procuramos orientar o trabalho no sentido de apontarmos para este nexo político da cidadania entre a população da cidade e o seu território.

O território se impõe como uma condição continente ao conteúdo político da cidadania e ao nível de organização social, cultural e econômica existente. De modo que fora dele (território) a cidadania torna-se uma abstração contida nos artigos da lei, sem formato definido por práticas específicas. Para Milton Santos (1987: 5), a vida social requer um componente cívico que "supõe a definição prévia de uma civilização que se quer, o modo de vida que se deseja para todos, uma visão comum do mundo e da sociedade, do indivíduo enquanto ser social e das suas regras de convivência".

Assim, pretendemos neste trabalho percorrer a diversidade histórica do conceito de cidadania, buscando assinalar a sua relação com a cidade enquanto fato geográfico, visando a sua (re)atualização face às transformações que se operam nas sociedades contemporâneas.

\section{Cidade e cidadania na polis grega}

A cidadania na Grécia antiga surge de um encontro político entre a cidade e o seu território na polis ou Estado. A expressão polis, que daria origem à palavra política (politikos: adjetivo que queria dizer "relativo à "polis" - BOBBIO, 1990: 954), designava ao mesmo tempo a Cidade, seu território, e o seu poder político, o Estado, de tal modo que um não era concebido sem o outro. Assim, na língua grega, polis é ao mesmo tempo uma expressão geográfica e uma expressão política, é a Cidade-Estado.

Segundo Glotz (1928), em sua obra La cité grecque, as condições geográficas da Grécia contribuíram muito para lhe dar o seu aspecto histórico, ao facilitar a delimitação territorial entre as Cidades-Estados. Como ele mesmo descreve: 
Recortada pelo contínuo encontro do mar com a montanha, apresenta por toda parte estreitas depressões emolduradas por elevações, que só têm entrada fácil pelo mar. Forma, assim, numerosos cantões, cada um dos quais é receptáculo natural de uma pequena sociedade. A fragmentação física determina, ou pelo menos facilita, a fragmentação política. Tantos compartimentos, tantas nacionalidades distintas. Imagina-se, num vale fechado, pastos à margem dos riachos, bosques nas encostas, campos, vinhedos e olivais que bastam para alimentar algumas dezenas de milhares de habitantes, raramente mais de cem mil, e depois um outeiro que pode servir de refúgio em caso de ataque e um porto para as relações exteriores; assim se terá uma idéia do que é para um grego um Estado autônomo e soberano. (p. 2)

Embora o fenômeno geográfico e o fenômeno político caminhem lado a lado, o Estado, como poder político, era muito mais vasto do que a cidade.

Além do território ocupado pelos citadinos, compreende o território agrícola, o campo ao redor, a Ática cheia de fazendas e de aldeias (...) Na política, porém, a polis (Cité) corresponde com mais exatidão à noção que hoje é a do Estado do que à idéia de 'cidade' (ville). (DEFOURNY, 1932: 466)

Na Grécia antiga, contudo, a cidadania era seletiva e restrita. Assim, somente era considerado cidadão aquele que detinha poderes públicos, ou seja, podia escolher representantes nas assembléias, julgar e exercer funções ou cargos públicos. Em suma, ter uma participação direta e ativa no Estado. Desta condição encontravam-se excluídas as crianças, as mulheres, os escravos e os metecos, como o foi o próprio Aristóteles (pessoa sem direitos públicos, meramente tolerado por ser estrangeiro ou exilado e que pagava uma dada quantia anual para não ser vendido como escravo), um cidadão imperfeito, como ele mesmo definia.

Portanto, o fato de ter nascido ou habitar uma dada Cidade (polis) não conferia necessariamente a uma pessoa a condição de cidadão, o que quer dizer que nem todo citadino era cidadão. Por outro lado, o cidadão de uma certa Cidade somente poderia exercer os seus poderes no território circunscrito àquela polis.

Segundo Clarke (1994: 6-7), Sócrates teria preferido a morte a viver como nãocidadão no exílio, condenado ao ostracismo. Para um cidadão de uma polis grega, e sobretudo Atenas, a primeira a expressar completamente a idéia de cidadão, a pior humilhação que uma pessoa poderia passar era ser destituída de sua condição de cidadão, visto que o não-cidadão não era considerado inteiramente humano. Em outras palavras, ser humano era ser, antes de tudo, um ser político.

Como podemos notar, a idéia de cidadão, este "animal cívico" no dizer de Aristóteles (1991: 3), estava fortemente associada à noção de pertencimento a uma comunidade e a uma certa condição humana, que era geograficamente demarcada pelos contornos da polis. Esta situação é completamente distinta do que observa- 
mos hoje, quando "o simples nascer investe o indivíduo de uma soma de direitos, apenas pelo simples fato de ingressar na sociedade humana" (SANTOS, 1987: 7).

No seu livro A Política, Aristóteles (1991) exemplificaria, assim, as virtudes que fazem o cidadão e o homem de bem:

Podemos comparar os cidadãos aos marinheiros: ambos são membros de uma comunidade. Ora, embora os marinheiros tenham funções muito diferentes, um empurrando o remo, outro segurando o leme, um terceiro vigiando a proa ou desempenhando alguma outra função que também tem seu nome, é claro que as tarefas de cada um têm sua virtude própria, mas sempre há uma que é comum a todos, dado que todos têm por objetivo a segurança da navegação, à qual aspiram e concorrem, cada um à sua maneira. De igual modo, embora as funções dos cidadãos sejam dessemelhantes, todos trabalham para a conservação de sua comunidade, ou seja, para a salvação do Estado. Por conseguinte, é a este interesse comum que deve relacionar-se a virtude do cidadão. (p. 41)

A cidadania, portanto, não implicava a homogeneidade de funções e a igualdade de virtudes, mas não podia existir sem a noção de pertencimento a uma comunidade, o espírito de bem comum e a segurança do Estado.

Para Aristóteles (1991: 1), o Estado representa a esperança de um bem que contém o princípio da sociedade e de toda associação, como regente e regulador da ação humana que tem por fim último a felicidade. E esta felicidade só alcançaria a sua plenitude no seio da Cidade.

As Cidades inicialmente foram, como ainda hoje o são algumas nações, submetidas ao governo real, formadas que eram de reuniões de pessoas que já viviam sob um monarca. Com efeito, toda família, sendo governada pelo mais velho como que por um rei continuava a viver sob a mesma autoridade, por causa da consangüinidade. (ARISTÓTELES 1991:3)

As Cidades proporcionam, portanto, a congregação de famílias dispersas (população) e o poder num mesmo território submetido à autoridade de um monarca (governo). De outro modo, as Cidades surgem como um produto da sociedade hierarquizada, da dominação pai-filho, homem-mulher, senhor-escravo, rei-súditos.

A sociedade que se formou da reunião de várias aldeias constitui a Cidade, que tem a faculdade de se bastar a si mesma, sendo organizada não apenas para conservar a existência, mas também para buscar o bem-estar. Esta sociedade, portanto, também está nos desígnios da natureza, como todas as outras que são seus elementos. Ora, a natureza de cada coisa é precisamente o seu fim. (ARISTÓTELES, 1991:3-4) 
A Cidade seria o desaguadouro inevitável do desenvolvimento natural do homem, como também projetar-se-ia sobre ela a realização de um ideal de bemestar. Assim, passado e futuro se encontrariam na Cidade e a cidadania como um ideal de felicidade se confundiria com a própria vida no interior da polis, onde política e território encontravam-se indissoluvelmente ligados.

\section{A cidadania rompe as fronteiras da cidade}

Durante o Império Romano a noção de cidadania foi gradativamente adquirindo uma dimensão mais abstrata e autônoma em relação ao território da Cidade (urbis). A cidadania assume um valor simbólico que passa a ser incorporado pelo indivíduo qualificado como cidadão. Assim, o cidadão de Roma era considerado e respeitado como tal em todo o Império, para além do território da urbis. Perseguido por difundir os ideais cristãos, Paulo utilizou-se desta condição de cidadão romano para escapar algumas vezes da prisão e da morte em seu trabalho de peregrinação (CLARKE, 1994: 8).

A cidadania, assim como as cidades, assumiria uma forma múltipla e extensiva a todo o Império, tendo como referência central a cidade de Roma.

O Império Romano, produto de um único centro urbano de poder em extensão, foi em si mesmo uma vasta empresa construtora de cidades: deixou a marca de Roma em todas as partes da Europa, da África do Norte e da Ásia Menor, alterando o modo de vida em cidades antigas e estabelecendo seu tipo especial de ordem, a partir do chão, em centenas de novos alicerces, cidades 'coloniais', cidades 'livres', cidades sob a lei municipal romana, cidades 'tributárias': cada qual com uma condição diferente, senão uma forma diferente. (MUMFORD, 1965: 269)

Roma, portanto, universaliza o modo urbano, transformando outras culturas, em toda a sua variedade de forma e conteúdo. Ao contrário da Grécia, onde cada Cidade correspondia a uma forma autônoma de poder político e cultural, corporificada na polis, Roma encobre a diversidade com uma espécie de uniformidade político-cultural. Por outro lado, enquanto o conceito de cidadania na Grécia expressase de maneira rígida no par cidadão/não-cidadão, no Império Romano ele se desdobra em mais de um tipo.

Havia os cidadãos de primeira linha, os patrícios, portadores de uma cidadania ativa, que participavam diretamente do poder político e da administração do Estado, e os plebeus, não-proprietários, que detinham a cidadania de maneira passiva, incorporando-a apenas como um status (CLARKE, 1994: 8). Desse modo, a cidadania era, para a vasta maioria da população, uma condição que implicava alguns direitos e deveres mas que excluía do direito ou dever de participar da vida 
política do Estado. Cabia aos plebeus habitar, freqüentar e participar da vida comunitária e cultural da urbis, estando vetado a eles, no entanto, a presença em alguns rituais religiosos do alto ofício.

Em suma, a cidadania, embora seletiva e restrita como na Grécia, tornou-se diferenciada e mais complexa no Império Romano, assumindo níveis distintos entre as classes sociais e incorporando um valor simbólico que estende a sua dimensão geográfica para além do território da cidade-referência, no caso Roma. Com efeito, ampliou-se a sua escala de ação e influência.

\section{A cidade metafísica: a dissolução do nexo político da cidadania}

No século V, na crise do Império Romano, a noção de cidadania assumiria uma dimensão metafísica ou, por assim dizer, sucumbiria diante da formulação filosófica proposta por Santo Agostinho, que tanta força teria durante a Idade Média. Na abertura do Livro I, da obra La cité de Dieu, este pensador exemplificaria muito bem tal idéia:

A gloriosa cidade de Deus, seja aqui embaixo no curso do tempo em que ela persegue sua peregrinação, vivendo da fé em meio à impiedade; seja na estabilidade do descanso eterno que ela espera agora com paciência, até o dia em que 'a justiça será transformada em julgamento' e em que ela obterá uma vitória última e uma paz perfeita...(AUGUSTIN, Saint,1994: 34)

A Cité de Dieu (ou a Cidade de Deus) desloca para o plano divino a propriedade de eleger seus representantes aqui na Terra e de julgar todos aqueles que estão abaixo de Deus e suas leis. Assim, em oposição à Cité des hommes, mítica, pagã e politeísta, constituída de cidadãos e não-cidadãos, aparecerá a Cité de Dieu, de um Deus único e verdadeiro, constituída de servos do Senhor.

A decadência do Império Romano e o colapso da cidade de Roma forneceram a evidência histórica em que tais idéias ganharam alimento para se desenvolver. É diante da morte, da ruína, da pilhagem, do incêndio, da desolação e do horror que se abateu sobre os homens que se construirá o edifício da fé cristã voltada para a conquista da felicidade fundada numa busca interior e na justiça divina.

A idéia de vida após a morte e do juízo final, do qual nenhum mortal estaria de fora, faz emergir uma visão linear de tempo e ambígua de história. A ética e a moral tornam-se assuntos de ordem religiosa e a vida na Terra passa a ser encarada como uma etapa para se alcançar o Reino dos Céus, isto é, para aqueles que, segundo o julgamento divino fossem merecedores.

Desse modo, a cidadania como ideal de bem-estar e felicidade ganha uma dimensão metafísica, bem como a sua geografia (a "cidade"), e o homem, de "animal cívico", passa a ser valorizado por sua religiosidade e submissão à vontade de 
Deus. A idéia de pessoa irá se sobrepor, então, à idéia de cidadão e, ao contrário da vida na Grécia e no Império Romano, onde a noção de homem de bem baseava-se no reconhecimento público de suas virtudes cívicas, passa a dominar a idéia de que o reconhecimento divino é o verdadeiramente importante e de que ele independe da sua condição e posição na sociedade (CLARKE, 1994: 9-12).

Por esta via, o que importa é que cada pessoa, indiferentemente da cidade onde tenha nascido, da sua origem social ou do seu nível de participação política compartilharia de uma mesma visão de "cidade divina", rompendo-se, assim, o nexo político entre o território e seus habitantes que caracterizava a cidadania. A noção de pertencimento a uma comunidade era considerada como útil, até onde as regras de urbanidade não se chocassem com os preceitos da fé. Para Sennett (1997: 128), ao distinguir as "duas cidades", Santo Agostinho ajustou-se "à regra de ouro da doutrina cristã, segundo a qual a Cidade de Deus não é um lugar".

\section{0 retorno às cidades e a reconstituição do nexo político da cidadania}

Após ter observado uma flagrante involução no seu desenvolvimento histórico, do século V ao século XII, as cidades européias retornariam à cena na Baixa Idade Média e o nexo político da cidadania entre a população, o Estado e o seu território, que fora deslocado para o plano divino, seria, gradativamente reconstituído, sendo que agora sob novas bases. O Humanismo (séc. XIV) e o Renascimento (séc. XV) reforçariam ainda mais esta tendência.

Se na antiga Grécia e em Roma dava-se ênfase à vida pública, agora é a noção de vida privada, centrada no indivíduo, que se desenvolverá. É da normatização deste indivíduo e seus direitos que emergirá o novo modelo de cidadania juntamente com o Estado Moderno. Nas cidades, os homens passam a ser vistos como indivíduos portadores de iniciativa e conhecimentos que, para serem exercitados, precisavam de liberdade para ir e vir e para expressar suas idéias. Nessa época, muitas cidades (burgos) se transformam em signo de liberdade.

Max Weber (1947) já apontava a distinção entre a cidade medieval e a cidade antiga no Ocidente na sua característica de coletividade de produtores individuais. Enquanto a cidade antiga reunira mais atributos de consumidora e tivera seu papel definido por fins políticos e militares, a cidade medieval inaugura uma sociedade fundada sobre a associação livre de produtores. Estes homens criaram uma nova concepção e uma nova prática de legitimidade política baseada na associação de interesses econômicos da burguesia. A cidade tornou-se autônoma, possuindo seus próprios direito e governo, justiça, finanças e defesa organizadas por ela mesma. Nela, o cidadão é concebido em termos estritamente individuais.

Segundo Le Goff (1990: 19), a cidade modifica o homem medieval. Ela restringe o seu círculo familiar e amplia a rede de comunidades nas quais ele atua. 
Surgem novas preocupações materiais, em cujo centro coloca-se o dinheiro e, à sua frente, a burguesia emergente.

As cidades são centros de irradiação na circulação dos homens, tão plenas de idéias como de mercadorias, lugares de trocas, mercados e encruzilhadas do comércio intelectual. (LE GOFF, 1990:25).

O aumento da circulação monetária e a organização das redes comerciais forçam os citadinos a construir uma medida de tempo mais de acordo com a organização dos negócios. Até então cabia ao poder eclesiástico a organização do calendário e do tempo, impondo uma disciplina religiosa à vida cotidiana. A burguesia nascente se apropria do calendário e da medida do tempo a fim de organizar a população da cidade de acordo com uma disciplina laica de trabalho, recém descoberta (LE GOFF, 1983: 19).

O tempo deixa de ser um monopólio de Deus e da Igreja e pode ser agora manipulado pelo homem da cidade. O tempo "natural" ou rural é, aos poucos, substituído pelo tempo "artificial" ou urbano que rege o mundo dos negócios. A idéia de um tempo de vida linear ou contínuo, que se estende para além da morte, será também, gradativamente, posto em questão, na medida em que avançar o processo de laicização.

Outra transformação importante, que contribui para redesenhar a natureza humana do homem medieval, é a que ocorre com a própria Igreja. A luta pelo controle do tempo, e dos símbolos de tudo aquilo que era considerado sagrado, gera também uma luta pelo controle do espaço, o que se traduz em uma competição pela cidade e pelos seus novos componentes sociais - burgueses, artesãos e intelectuais - possíveis fiéis ou mesmo aliados políticos. Portanto, a Igreja não ficará passiva diante de tais transformações históricas polarizadas ao redor das cidades. Segundo Sennett (1997: 136), juntamente com o renascimento das cidades há também um renascimento religioso.

Ocorre nesse período um deslocamento de parte do corpo da Igreja para as cidades. A catedral é a igreja do bispo e para cada bispo há uma cidade. Para Duby (1990: 29), a arte das catedrais significa "o despertar das cidades", a exemplo de Paris que, nesse momento, se encontra no centro de todas essas transformações. A cidade, desde então, vai se constituindo em um espaço de contrastes sociais e a catedral se apresentará como a possibilidade de salvação, tanto para a população miserável quanto para os homens enriquecidos que, temendo, ainda, a justiça de Deus, queiram investir na sua construção em troca da salvação de sua alma.

A catedral tinha presença expressiva na cidade, não só na sua paisagem, mas também na organização da sua vida cotidiana. No seu interior, burgueses se reuniam nas suas confrarias, promovendo assembléias civis e vindo a ela também para rezar. A catedral é, assim, juntamente com o mercado, o local de convergência do 
povo da cidade. Como as muralhas da cidade, a catedral é uma fortaleza e com suas torres ela proclama a sua soberania sobre a paisagem.

Na segunda metade do século XIII e início do século XIV ocorre um deslocamento espacial do eixo de maior vigor econômico e cultural da França para o Norte da Itália, e com ele ganha maior visibilidade o processo de dessacralização, essencial na compreensão da formação do chamado indivíduo moderno. Nas cidades italianas dessa época sente-se uma necessidade de afirmação, culturalmente diferente, sobre o legado de Bizâncio, do Sacro Império Romano Germânico, bem como sobre outras cidades italianas que são rivais, política e comercialmente, daquelas do Norte. Estas são as cidades das comunas e das guildas, repúblicas governadas por famílias patriarcais, mas que se tornaram importantes através das mãos dos homens de negócios, burgueses e mercadores. Nelas a vida não se organiza em torno da catedral e sim em torno da praça, onde o edifício religioso dividirá o seu lugar com o palácio comunal que se ergue, majestoso e imponente, em frente à catedral.

Ainda no século XIV, as escalas do sagrado atingem o plano do indivíduo, passando, gradativamente, do monumental da catedral para o pessoal dos pequenos objetos de culto. Objetos cativos que são feitos para serem guardados perto de si, para proteger o seu dono. Nesse processo, a oração passa progressivamente a ser mais pessoal. O sentido do gótico, de pôr Deus em contato com o homem e com as coisas mundanas, ainda se encontra presente; contudo, adquire, nesse momento, um significado de posse, de privado, à disposição do indivíduo.

As representações do espaço vão, durante esse período, se dessacralizando. De uma representação monástica e ascética passa-se a uma representação aberta e ligada ao mundo, cujo foco está sobre o indivíduo. Se os bens e a riqueza em geral não podem ser repartidos com eqüidade, num mundo socialmente injusto e desigual, o fim do monopólio da Igreja sobre as representações do mundo, assim como dos seus conteúdos, gerou, no indivíduo, a ilusão do igual ou da sua possibilidade, na medida em que ele passava a ter contato e/ou acesso a um mundo de representações simbólicas antes a ele vedado. Segundo Max Weber, "o cidadão medieval estava prestes a converter-se em um homem econômico", já bastante distanciado do "cidadão antigo, que era um homem político" (apud SENNETT, 1997: 136).

Chegamos ao século XV em plena Renascença, onde todo esse processo de dessacralização e laicização tem a sua primeira culminância, chegando finalmente a ser apreendido pelo indivíduo. Neste momento as condições históricas para o surgimento do Estado Moderno já estão postas.

A cidade dentro desse contexto é privilegiada por concentrar no seu espaço boa parte de todas essas transformações, desempenhando um papel importante por ser um espaço de aglutinação. No entanto, não devemos entendê-la como uma oposição ao mundo feudal, uma vez que ela não representa em si mesma uma ruptura, mas uma continuidade contraditória desse mundo. Nesse sentido, a cidade não foi uma negação, mas sim parte integrante desse mundo, completando-o e completan- 
do-se até que os próprios limites do feudalismo colocassem barreiras de outra ordem e escala, ao funcionamento do mercado e às ambições da burguesia.

Do mosteiro à catedral, da catedral à praça, da praça ao palácio, este foi o caminho da dessacralização e da (re)montagem de um novo sistema de representações simbólicas, com feixes no mundo e prisma no indivíduo. Podemos notar que para cada momento histórico dessa trajetória há uma forma/objeto espacial ou lugar para onde convergem a competição simbólica entre as classes e os grupos da sociedade. Uma espécie de "espaço amálgama", que se constitui num palco privilegiado das disputas sociais, em nível de representações.

Paradoxalmente, a valorização do indivíduo, numa escala social mais ampla, nasce junto com o Estado Moderno, com o absolutismo e com o despotismo. "Em toda parte, o que vemos são agentes individuais e seus atos, e o que se descreve são suas fraquezas e talentos pessoais", menciona Elias (1993: 16) ao fazer alusão aos reis e príncipes que se notabilizaram nessa época. Se cabia já à burguesia comandar a economia, cabia ao príncipe ou ao Rei, por outro lado, ditar e reger o padrão das relações sociais e suas hierarquias através da centralização do poder.

Se o prisma está sobre o indivíduo, o comportamento pessoal passa a ser algo importante, sobretudo quando este indivíduo está exposto à observação em "ambientes públicos". O espaço público ou os espaços de exposição à observação pública passam a ser lugares de controle; controle dos movimentos, gestos, fala e emoções e onde as relações familiares, parentais e de vínculos aristocráticos se imbricavam com o desempenho social público do indivíduo.

Este "jogo de representações" tende a levar o indivíduo, através das pressões exercidas sobre ele na sociedade, a uma racionalidade distintiva, uma tutela dos afetos, uma autodisciplina e um autocontrole. Segundo Elias, o modelo de autocontrole é:

... o gabarito pelo qual são moldadas as paixões e varia de acordo com a função e a posição que o indivíduo ocupa no sistema de relações sociais. A estabilidade do "aparato de autocontrole mental" que emerge como traço decisivo, embutido nos hábitos de todo o ser humano “civilizado", mantém a relação mais estreita possível com a monopolização da força física e a crescente estabilidade dos órgãos centrais da sociedade. Só com a formação desse tipo relativamente estável de monopólios é que as sociedades adquirem realmente estas características, em decorrência das quais os indivíduos que as compõem sintonizam-se, desde a infância, com um padrão altamente regulado e diferenciado de autocontrole; só em combinação com tais monopólios é que esse tipo de autolimitação requer um grau mais elevado de automatismo, e se forma, por assim dizer, uma "segunda natureza". (p. 197).

Neste sentido é somente por meio do autocontrole que o indivíduo pode transladar-se da natureza mais instintiva e primitiva para o estado de homem "civilizado". Assim, "civilizar" significa, de um lado, centralizar o poder, exercendo o monopó- 
lio da força física, e, de outro, submeter-se ao padrão social de conduta com base no autocontrole.

Esse padrão de relações "suavizado", "polido" e "civilizado" que chamou a atenção de Elias na sociedade de corte, contém, guardadas as devidas proporções, o gérmen do modelo de autocontrole, no que tange aos seus mecanismos sociais e psicológicos, que regula a conduta do indivíduo contemporâneo. O cidadão de hoje, no nosso entender, nada mais é do que a "civilização" do indivíduo ou sua normatização político-social, que se apresenta geograficamente diferenciada, aqui e ali, enquanto possibilidade histórica.

Refletindo sobre a noção de modernidade, Alain Touraine (1995: 21) enfatiza que a imagem de um mundo guiado pela razão em que tradições, crenças e privilégios dão lugar aos valores universalistas da ciência e do direito é aquela que se impõe como dominante. A nova forma da cidade deveria expressar o moderno, o Estado de direito e a sua tradução em convívio cotidiano através de um savoirvivre, de uma civilidade que os franceses chamam de citadinité para distinguir da cidadania vinculada à nacionalidade por eles denominada citoyenneté. A cidade será o pólo central para onde convergirá o Estado de direito devendo, portanto, espelhar a modernidade.

\section{A cidadania como nacionalidade, a cidade como símbolo}

O novo modelo de cidadania em gestação teve por base o surgimento do Estado Moderno e, por cimento, a noção de indivíduo que emergirá, como realidade histórica, a partir do século XII, com o renascimento das cidades e a entrada em cena do homo economicus.

Segundo Sennett (1997), este homem

...vivia no espaço e não para o lugar. A corporação, desde que a Revolução Comercial propiciou maior prosperidade, identificou tempo e espaço na sua estrutura flexível - permanentemente mutável (...) Na sociedade moderna, o peso do individualismo é tão insustentável que afasta da imaginação o altruísmo e a piedade como essenciais à conduta humana. (pp. 175-6)

Contudo, este novo modelo de cidadania só se efetivará quando este homo economicus e demais indivíduos autônomos em associação se rebelarem contra o poder do Estado Absoluto e contra a tutela da Igreja, transformando-se em sujeitos. Assim, foram as Revoluções Liberal Inglesa (séc. XVII) e Francesa (séc. XVIII) que firmaram na sociedade as estacas do contratualismo como uma nova forma de regulação da vida política e social dos homens. 
A função reguladora da nova cidadania sobre a sociedade compreenderá, em um sentido mais amplo, um "acordo de regras de convivência", um "pacto de classes" ou um "contrato social", como ficou mais conhecido modernamente.

O primeiro filósofo a enfocar esta discussão foi Hobbes, contemporâneo da Revolução Democrática Inglesa de 1648. Pressionado pela realidade da "guerra civil", Hobbes (1974: 82) calcado na premissa da lei de natureza, como "um preceito ou regra geral, estabelecido pela razão, mediante o qual se proíbe a um homem fazer tudo o que possa destruir sua vida ou privá-lo dos meios necessários para preservá-la", chegaria, assim, à idéia de contrato:

Desta lei fundamental de natureza, mediante a qual se ordena a todos os homens que procurem a paz, deriva esta segunda lei: Que um homem concorde, quando outros também o façam, e na medida em que tal considere necessário para a paz e para a defesa de si mesmo, em renunciar a seu direito a todas as coisas, contentando-se, em relação aos outros homens, com a mesma liberdade que aos outros homens permite em relação a si mesmo. Porque enquanto cada homem detiver seu direito de fazer tudo quanto queira todos os homens se encontrarão numa condição de guerra (...)

Quando alguém transfere seu direito, ou a ele renuncia, fá-lo em consideração a outro direito que reciprocamente lhe foi transferido, ou a qualquer outro bem que daí espera. Pois é um ato voluntário, e o objetivo de todos os atos voluntários dos homens é algum bem para si mesmos (...)

A transferência mútua de direitos é aquilo a que se chama contrato. (HOBBES, 1974:8384)

Para Gruppi (1980: 13), "a noção do Estado como contrato revela o caráter mercantil, comercial das relações sociais burguesas". Hobbes, no entanto, faria uma diferenciação entre o contrato e o pacto. Este último, no seu entender, seria uma situação particular do primeiro.

Há uma diferença entre a transferência do direito a uma coisa e (...) a entrega da própria coisa. Porque a coisa pode ser entregue juntamente com a translação do direito, como na compra e venda com dinheiro à vista, ou na troca de bens e terras; ou pode ser entregue algum tempo depois.

Por outro lado, um dos contratantes pode entregar a coisa contratada por seu lado, permitindo que o outro cumpra a sua parte num momento posterior determinado, confiando nele até lá. Nesse caso, da sua parte o contrato se chama pacto ou convenção. (HOBBES, 1974:84)

No seu clássico, Do Contrato Social, Rousseau não faria nenhuma distinção entre pacto e contrato, ao contrário, os usaria eventualmente como expressões sinônimas. No seu entender, para viver em sociedade, cada um de nós "dá-se com- 
pletamente", ou seja, submete aos padrões coletivos todos os impulsos naturais da criatura individual, sendo tal submissão, porém,uma "condição igual para todos".

Encontrar uma forma de associação que defenda e proteja a pessoa e os bens de cada associado com toda a força comum, e pela qual cada um, unindo-se a todos, só obedece contudo a si mesmo, permanecendo assim tão livre quanto antes. Esse, o problema fundamental cuja solução o contrato social oferece. (...)

Essa pessoa pública, que se forma, desse modo, pela união de todas as outras, tomava antigamente o nome de cidade e, hoje, o de república ou de corpo político, o qual é chamado por seus membros de Estado quando passivo, soberano quando ativo, e potência quando comparado a seus semelhantes. Quanto aos associados, recebem eles, coletivamente, o nome de povo e se chamam, em particular, cidadãos, enquanto partícipes da autoridade soberana, $e$ súditos enquanto submetidos às leis do Estado. (1973: 38-39)

Em suma, cidadão é aquele que confere a autoridade soberana e se submete às leis do Estado e sua normatização, em nome de um bem comum e uma promessa de felicidade. Para Rousseau, a natureza humana é livre e propensa à associação e é desta capacidade de livre associação que brota o sujeito na sua ação individual ou coletiva.

Rousseau enfatiza o pólo da liberdade e da autonomia em relação ao futuro, ao passo que Hobbes o considera um risco à subversão, concedendo maior ênfase à ordem no presente.

O debate acerca da liberdade e os seus limites para o indivíduo estaria na base da formulação liberal do Estado contratual e do seu cidadão.

Locke, fundador do empirismo filosófico moderno e teórico da Revolução Liberal Inglesa (1689), observa que:

...o homem no estado natural está plenamente livre, mas sente a necessidade de colocar limites à sua própria liberdade (...) a fim de garantir a propriedade. (...) A relação entre propriedade e liberdade é extremamente evidente: o poder supremo não pode tirar do homem uma parte de suas propriedades sem o seu consentimento. Pois a finalidade de um governo e de todos os que entram em sociedade é a conservação da propriedade. (apud GRUPPI, 1980: 13-15)

A relação indissociável entre propriedade e liberdade seria uma das essências do liberalismo, trazendo à tona, novamente, a exemplo do que ocorrera na Roma antiga, a distinção entre cidadãos proprietários e cidadãos não-proprietários. Para Kant, 
...há cidadãos independentes e cidadãos não-independentes. Aqueles independentes - os que podem exprimir uma opinião política, que podem decidir da política do Estado - são cidadãos que não dependem de outros, isto é, os proprietários. Não se pode pensar que sejam capazes de uma opinião independente os servos das fazendas, ou os aprendizes das oficinas artesanais. Por conseguinte, eles não podem ter o direito de voto, nem de serem eleitos. Os direitos políticos ativos cabem somente aos proprietários. (apud GRUPPI, 1980:16)

Esta polêmica entre esses dois tipos de cidadãos, o cidadão ativo e o cidadão passivo, se fez presente, de maneira crucial, na primeira fase da Revolução Francesa.

A Revolução Francesa, e o cidadão que dela brotou, consagrará uma forma de encarar a vida, o indivíduo, a política e a cidade, que vai para além de um simples estatuto de direitos e deveres ou código de posturas. Emerge, então, uma concepção que se gestara ao longo do processo das lutas que levaram à subordinação de liberdades, imunidades e privilégios feudais de senhores e corporações. Estabelece-se uma definição de cidadania abstrata e formal, cujo núcleo é a idéia de um atributo geral, extensivo a todo membro pertencente à sociedade (STEWART, 1995: 65).

Segundo Brubaker (apud Stewart, 1995: 65), a Revolução elevou ao nível nacional elementos que vinham se desenvolvendo durante o Antigo Regime, tais como as mediações que se introduziram na relação entre o indivíduo e o Estado, substituindo relações diretas e imediatas. Da mesma forma, ganham novo alcance, a partir daí, a racionalização legal e a distinção entre cidadãos e estrangeiros, bem como a articulação de uma doutrina de soberania nacional. $\mathrm{O}$ estabelecimento da igualdade civil, incluindo direitos e deveres partilhados e a institucionalização de direitos políticos são contribuições fundamentais para a nova face da cidadania desenhada pela mentalidade revolucionária.

Após a Revolução, a palavra cidadão adquire dois significados. O primeiro deles identifica o indivíduo que nasceu ou que porta a nacionalidade de um determinado país. O segundo refere-se ao portador de direitos cívicos, tais como o direito de voto, a elegibilidade, funções públicas, porte de arma, funções de tutor, curador, testemunha, etc. (LOCHAK, 1992: 11-12). Logicamente, esses dois significados aparecem associados, ao mesmo tempo em que são atravessados pelos pressupostos da liberdade e da igualdade.

Apesar de suas origens longínquas, as noções de cidadão e de nação adquiriram um valor sob a Revolução Francesa que se impôs não só para a ideologia republicana francesa, mas como parte de um ideário assimilado pelos países ocidentais, inclusive as jovens nações do continente americano. Assumiram, entretanto, feições que se moldaram à especificidade das diversas realidades histórico-geográficas em que se inseriram. 
Nota-se, entretanto, que a aproximação dessas duas noções de modo a se consolidarem num conceito que une o cidadão e o nacional, decorre de um processo que se desdobra ao longo do século XIX.

No caso francês, durante a primeira metade do século XIX predomina o pensamento em que o cidadão é definido por uma adesão ao contrato social, sem a exigência da nacionalidade. A Constituição revolucionária de 1793 estendia a qualificação de cidadão a todos os que haviam dado provas de atos cívicos e trabalhado pela Revolução, mesmo que não fossem franceses. Somente no recenseamento de 1851 resolve-se levantar quantos são os estrangeiros que habitam o território francês. Para Catherine de Wenden (1992: 39), somente ao final do século XIX a cidadania francesa se cristalizou em torno do "mito da homogeneidade nacional e da comunidade cultural, celebrada e ensinada tanto por filósofos (Taine, Renan) quanto pelos fundadores do Estado-nação da IIIa. República". Consolida-se, então, o par cidadania-nacionalidade.

Stewart (1995: 66), por outro lado, chama a atenção para as nuances que o par cidadania-nacionalidade assumiu em diferentes regiões européias. Enquanto na França a concepção de nação está fincada na estrutura institucional e territorial do Estado, na Alemanha - onde o sentimento nacional antecede a existência do Estado-nação - desenvolve-se uma cidadania formal referenciada em pressupostos de exclusão e não de inclusão. Já na Inglaterra, a idéia de Império Britânico se sobrepôs à de nação, apoiada pela predominância de um status legal e político pensado em termos de uma relação entre sujeitos individuais e o rei, mais do que entre membros de uma comunidade política.

Esse panorama diversificado da relação entre cidadania e nacionalidade ajudanos a distinguir características próprias da cidadania, também na história brasileira. De outro lado, deixa entrever a complexidade dessa relação que se liga a uma das contradições mais importantes no interior da concepção moderna de cidadania. Ao mesmo tempo em que, modernamente, esse conceito se ampliou, adquirindo uma dimensão universal - para a qual a contribuição da Revolução Francesa foi fundamental - sua construção histórica ocorreu associada ao nacionalismo e atravessada pelas divisões que a sociedade burguesa fazia reproduzir.

A Declaração dos Direitos do Homem e dos Cidadãos, de 1789, conferiria aos direitos do homem e dos cidadãos um status sagrado e único, de tal modo que os direitos dos cidadãos não poderiam ser tomados como separados dos direitos humanos. O homem passaria a ser em si, a partir do momento em que nascesse, um cidadão. Assim, cidadania e pertencimento ao corpo político estariam garantidos a todo homem, independente da sua condição social.

Este ideal de cidadania ativa e participativa, tendo por princípio a relação indissolúvel entre homem e cidadão, logo sofreria um golpe, desdobrando-se numa cidadania seletiva, segundo o poder econômico de cada indivíduo. Em outubro de 1789, se impõe o projeto de cidadania de dois níveis, a dos cidadãos participantes e dos cidadãos não-participantes, introduzindo-se uma taxa para votar. 
Robespierre, até a sua morte na guilhotina em 1794, seria um ferrenho opositor e crítico desta decisão. Segundo ele, tal sistema de votação negava a declaração e violava os direitos humanos. "A sociedade é um contrato entre o vivo, o morto e o que ainda não nasceu" e a Revolução estava quebrando este contrato (CLARKE, 1994: 16-17). Segundo Burke (apud CLARKE, 1994: 32), tal fato promoveu uma reviravolta no ideal de autonomia e um retorno à submissão política ao Estado como soberano, muito embora a Declaração apregoasse esta soberania ao povo.

Um novo sistema de votação, com base no sufrágio universal, só seria alcançado no século XIX, como conquista dos movimentos sociais e lutas dos trabalhadores por emancipação política.

Marx, em 1844, abordaria o complexo tema da emancipação política na sociedade burguesa, em seu texto A questão judaica, analisando criticamente o caso dos judeus face ao Estado cristão na Alemanha. Para ele, os judeus não poderiam emancipar-se politicamente como cidadãos sem emancipar-se como homens, abrindo mão dos próprios preceitos do judaísmo.

Ao colar a emancipação política à emancipação humana, Marx (1982: 28) o faz para distingui-las e mostrar a contradição que reside "na essência e na categoria da emancipação política", ao conceber um cidadão abstrato, separado do homem real, o indivíduo egoísta.

Este homem, membro da sociedade burguesa, é agora a base, a premissa do Estado político. E, como tal, é reconhecido nos direitos humanos.

A liberdade do egoísta e o reconhecimento desta liberdade são a expressão do reconhecimento do movimento desenfreado dos elementos espirituais e materiais que formam seu conteúdo de vida.

Por conseguinte, o homem não se libertou da religião; obteve, isto sim, liberdade religiosa. Não se libertou da propriedade, obteve a liberdade de propriedade. Não se libertou do egoísmo da indústria, obteve a liberdade industrial.

A constituição do Estado político e a dissolução da sociedade burguesa nos indivíduos independentes - cuja relação se baseia no direito, ao passo que a relação entre os homens dos estamentos e dos grêmios se fundava no privilégio - se processa num só e mesmo ato. Assim sendo, o homem enquanto membro da sociedade civil, isto é, o homem não-político, surge como homem natural. Os droits de l'homme aparecem como droits naturels, pois a atividade consciente de si mesma se concentra no ato político (...)

A revolução política dissolve a vida burguesa em suas partes integrantes sem revolucionar estas partes nem submetê-las à crítica. Conduz-se, em relação à sociedade burguesa, ao mundo das necessidades, do trabalho, dos interesses particulares, do direito privado, como se estivesse frente à base de sua existência, diante de uma premissa que já não é possível fundamentar e, portanto, como frente à sua base natural. Finalmente, o homem enquanto membro da sociedade burguesa, é considerado como o verdadeiro homem, como homme, distinto do citoyen por se tratar do homem em sua existência sensível e individual imediata, ao passo que o homem político é apenas o homem abstrato, artificial, alegórico, moral. O homem real só é reconhecido sob a forma do citoyen abstrato. (MARX, 1982: pp. 36-37) 
Assim, ao separar o indivíduo do cidadão, a sociedade burguesa separou também o seu corpo político (o Estado) da sociedade civil. Desse modo, a verdadeira idéia de cidadão é abstrata e falece no encontro com as necessidades humanas. Ao se tornar um dispositivo abstrato a cidadania se inclinou para qualidades jurídicas formais, presas à lei.

Para Clarke (1994: 21), ao contrário do que se pensa, o grande desafio da cidadania moderna não é produção das condições de igualdade, mas a convivência com identidades parciais exclusivas, a exemplo dos judeus.

O nexo político da cidadania entre a população, o Estado e o seu território será reconstituído, nesta época, porém sob novas condições. Se no passado ele teve como referência a cidade (polis) ou Cidade-Estado, na democracia moderna (contratual), este deslocou-se para o Estado-nação. Sua qualidade passou a ser dada pela nacionalidade e os seus limites territoriais pelos contornos geográficos das fronteiras nacionais.

A grande cidade será, então, o palco central da competição e (re)ordenamento simbólico dos valores e ideologia revolucionária. Nos primeiros anos da Revolução Francesa, tentou-se criar, em Paris, locais em que os novos cidadãos pudessem se sentir iguais e expressar sua liberdade.

O espaço total, sem obstrução nem limites, onde tudo fosse 'transparente' e nada escondido, definia a imaginação revolucionária da mais ampla liberdade, segundo o crítico Jean Starobinski. Assim, em 1791, o Conselho da cidade de Paris começou a derrubar as árvores e pavimentar os jardins da velha praça Luís XV, rebatizada de praça da Revolução (atual place de la Concorde). Todas as plantas desenhadas para o centro da cidade propunham um lugar sem vegetação ou quaisquer outros obstáculos, uma vasta plaza de superfície dura. De acordo com essa reforma, elaborada por Wailly, o enorme vazio central seria cercado por construções, sem ruas ou calçadas que o atravessassem. O projeto de Bernard Poyet acabava com as pontes sobre o Sena, eliminando a ligação com pequenas edificações que dificultavam seus acessos. Também em outros lugares da cidade, como Champ de Mars, os urbanistas revolucionários procuraram extensões livres de tudo o que prejudicasse o movimento e a visão. (SENNETT, 1997: 241)

Décadas mais tarde, e em um outro contexto histórico, o urbanista Haussmann, a serviço de Napoleão III, levaria este espírito de cunhar sobre a cidade as marcas do novo cidadão ao seu extremo, voltando-o contra os próprios sujeitos da revolução e seus ideais de liberdade, igualdade e fraternidade. Em suas Mémoires, Haussmann escreveria: "Rasgando a velha Paris, o bairro dos motins, das barricadas (...) A abertura da rua Turbino fez desaparecer do mapa de Paris a rua Transnonain" (HAROUEL, 1990: 113)

Em linhas gerais, o urbanismo de Haussmann se caracterizaria 
... pela criação de uma vasta rede de grandes artérias que cortam indistintamente o território da cidade (...) Uma nova estrutura feita em bulevares, avenidas e ruas largas sobrepõese à trama existente, criando uma forte hierarquia entre as vias novas e a maioria das vias antigas. Paralelamente, adota-se uma política extremamente ativa em matéria de equipamentos públicos: sistema viário, rede de esgoto, distribuição de água e gás, mercados cobertos, feiras, prefeituras, colégios, estações, casernas, prisões, hospitais, espaços verdes (...) As grandes vias de Haussmann impõem a toda Paris a mesma imagem de uma capital moderna. $O$ caráter uniformemente monumental das fachadas dissimula a realidade social das zonas atravessadas. Nos bairros populares como nos bairros aristocráticos é a mesma imagem da cidade que se impõe. (HAROUEL, 1990:112-113)

Se, por um lado, se pretendia dar a ilusão de uma perfeita homogeneidade urbana. Por outro,

... a burguesia investe nos imóveis que se constroem ao longo das vias, e no oeste de Paris constroem-se bairros novos inteiramente burgueses. As grandes obras expulsam da área central uma população modesta, e até indigente, que se aloja bem ou mal nas zonas mais deserdadas da cidade e nas afluências das fortificações. Enquanto que antes as diversas categorias sociais estão freqüentemente no mesmo imóvel, elas encontram-se a partir de então separadas de maneira radical. A burguesia reserva-se alguns bairros, algumas ruas. O urbanismo de Haussmann induz à formação, numa parte da cidade, de um espaço da burguesia. (HAROUEL, 1990:113)

Enfim, dos milhares de repartições, corredores, pátios e quartos de palácios, rigidamente controlados pela autoridade do rei e disciplinados pela instituição da "etiqueta", da sociedade de corte, passamos à cidade planejada, "racionalmente" controlada pelo Estado burguês e disciplinada pelo código de posturas do "modelo cívico" de cidadania. Em outras palavras, a "civilidade", o autocontrole e a autodisciplina, exercitados na sociedade de corte, parecem ter sido transpostos para a cidade burguesa, por aqueles que tanto freqüentaram as cerimônias do palácio, só que com uma diferença: se na sociedade da corte havia, ainda, uma certa pessoalidade que cunhava as relações, na cidade burguesa, ao contrário, as relações primam, via de regra, por uma impessoalidade, pois este é o "tom" do modelo de civilidade. Ser cidadão nesta nova cidade é saber, antes de mais nada, se comportar nos espaços públicos; é não incomodar o outro na rua e no trabalho; é ser discreto e oportuno ao abordar o outro quando a situação assim exigir.

Segundo Sennett (1993), na cidade grande que surge após o século XVIII, a linha divisória entre a vida privada e vida pública estaria muito bem demarcada, pois constitui essencialmente 
...um terreno onde as exigências de civilidade - encarnadas pelo comportamento público, cosmopolita - são confrontadas com as exigências da natureza - encarnadas pela família. (...) As tensões entre as exigências de civilidade e os direitos da natureza, manifestadas na partilha entre vida pública e vida privada no centro cosmopolita, não apenas se espalharam pela alta cultura da época como também a esferas mais mundanas. Essas tensões transpareciam nos manuais sobre a criação dos filhos, nos folhetos sobre obrigações morais e crenças de senso comum sobre os direitos do homem. Juntos, o público e o privado criaram aquilo que chamaríamos um 'universo' de relações sociais. (pp. 33-34)

Viver sob essas exigências é a arte (e a tensão) de ser cidadão na cidade moderna, pois representar o seu papel nesta geografia cosmopolita é uma tarefa, social e psicologicamente, nada fácil.

Desse modo, o projeto de cidadania na grande cidade irá se superpor e, às vezes, se confundir, no cotidiano, com a própria civilidade requerida ao homem moderno. O cidadão na grande cidade capitalista deve orientar a sua conduta por um código de ética seletivo e segregador do espaço urbano. Para muitos, tal fato somente foi possível devido ao papel disciplinarizador e regulador que o trabalho fabril exerceu sobre os indivíduos.

Na versão moderna de cidadania como nacionalidade, política, território e cultura se fundem numa mesma matriz, tendo como referência o Estado-nação e por espaço privilegiado a cidade, sobretudo as grandes cidades, a exemplo de Londres e Paris, locus de poder econômico e civil, que são tomadas como símbolos ou modelos desta nova territorialidade.

O cidadão como indivíduo politicamente emancipado representou um passo importante na conquista de direitos políticos anteriormente negados, porém insuficiente, uma vez que não supera o homem egoísta e o seu individualismo.

\section{A cidadania na cidade: um direito social}

Os marcos estabelecidos à cidadania na sociedade burguesa alargaram o fosso entre o cidadão, este ser político genérico, juridicamente formal, e o homem real, este "indivíduo voltado para si mesmo, para seu interesse particular, em sua arbitrariedade privada e dissociada da comunidade" (MARX, 1982: 33). Nestes termos, homo economicus e homo politicus são radicalmente separados.

Este homem egoísta, ao qual alude Marx, será alimentado pelo individualismo, que historicamente vincular-se-ia ao nacionalismo. Segundo Dumont (1993: 35), "a nação é precisamente o tipo de sociedade global correspondente ao reino do individualismo como valor" e que se expressa por meio do nacionalismo. Desse 
modo, o nacionalismo é o correspondente do individualismo na escala geográfica da nação.

Para Leca (1991: 189-190), o individualismo corrompe a cidadania, destruindo a vida em comum e os laços comunitários. "O individualismo atomiza, fragmenta e corrói todo grupo social, e transforma o indivíduo em juiz soberano de tudo", conjugando-se na economia capitalista com os interesses privados da exploração e do mercado.

O consumismo desenfreado dos dias atuais é um demiurgo do individualismo em larga escala. Este último refaz-se e nutre-se vorazmente do primeiro, a cada instante. Segundo Santos (1987),

A glorificação do consumo se acompanha da diminuição gradativa de outras sensibilidades, como a noção de individualidade que, aliás, constitui um dos alicerces da cidadania. Enquanto constrói e alimenta um individualismo feroz e sem fronteiras, o consumo contribui ao aniquilamento da personalidade, sem a qual o homem não se reconhece como distinto, a partir da desigualdade entre todos. (p. 35)

No seu entender, o consumo exercerá sobre o indivíduo um papel alienador funcionando como um "verdadeiro ópio, cujos templos modernos são os Shopping-centers e os supermercados (...), construídos à feição das catedrais". Assim, em lugar do cidadão tem-se "um consumidor, que aceita ser chamado de usuário" (SANTOS, 1987:34 e 13).

Em um ensaio pioneiro, Harold Laski, em 1928, abordaria os efeitos do consumo sobre a cidadania de maneira muito lúcida e precisa. Para ele,

O consumo é uma aceitação de alternativas impostas. O efeito disto é uma vida na qual não há contexto cívico. E também uma vida em que os “cidadãos” são tratados como objetos de utilidade, não estando engajados na autorealização. Se os homens não estão engajados na autorealização, se eles são um meio para um fim, mais do que finalidades em si mesmos, então eles são escravos, não verdadeiros cidadãos (...)

Um mundo que olha o proveito e a competição como fonte de bem estar é um mundo inimigo do projeto de cidadania. (apud CLARKE, 1994: 23-24).

Meio século mais tarde, Alasdair MacIntyre seria igualmente enfático em suas críticas ao consumo, como elemento deformador do projeto de cidadania.

O cidadão como consumidor é um cidadão divorciado de um concerto para o bem-estar geral, tendo atenção somente para os seus direitos e atividades de consumo e não para os deveres apropriados para o cidadão. (apud CLARKE, 1994:24) 
Para ele, numa visão um tanto pessimista, a força centrífuga do individualismo, exacerbada pelo consumo, fragmenta a sociedade, quebrando com os seus padrões cívicos e comunitários, podendo levá-la a uma nova barbárie.

Preocupado com a tensão permanente existente entre a cidadania, que contém em si a idéia de igualdade, e a sociedade de classes no capitalismo, que é inerentemente desigual, T. H. Marshall elaborou, após a Segunda Grande Guerra, uma teoria da cidadania centrada fundamentalmente na noção de eqüidade. Em Citizenship and Social Class procurou demonstrar que o conteúdo da cidadania mudou com o desenvolvimento do capitalismo enquanto sistema social e estrutura de classes. A cidadania moderna, apesar de ter surgido e se ancorado inicialmente nas relações de mercado, tornou-se antagônica a essas relações e à sociedade de classes (BARBALET,1993: 37).

Marshall distinguiu na cidadania três partes ou elementos constitutivos: civil, político e social.

O elemento civil é composto dos direitos necessários para a liberdade individual - liberdade da pessoa, liberdade de expressão, pensamento e credo, o direito à própria propriedade e de realizar contratos válidos, e o direito à justiça (...) Pelo elemento político eu quero dizer o direito de participar no exercício do poder político, como membro de um corpo investido de autoridade política ou como eleitor dos membros de tal corpo. As instituições que lhe correspondem são o parlamento e conselhos de governo local. Pelo elemento social eu me refiro a todo o âmbito que vai do direito a um módico bem-estar econômico e segurança até o direito de partilhar do todo da herança social e viver a vida de um ser civilizado de acordo com os padrões prevalecentes na sociedade. As instituições mais proximamente conectadas a este elemento são o sistema educacional e os serviços sociais. (1992: 8)

O novo na teoria de Marshall é que ele incorpora os direitos sociais como parte constitutiva da cidadania, dando a esta uma dimensão mais concreta e atualizada. $\mathrm{O}$ Estado teria papel destacado na constituição desses direitos. O direito à educação, aos serviços médico-hospitalares, ao lazer etc., como partes do elemento social e sua herança, tornam a cidadania mais palpável no dia-a-dia. Dentre esses serviços o papel da educação seria central, pois proporcionaria igualdade de oportunidades no processo de seleção e mobilidade social, considerado como direito dos cidadãos.

Tal formulação teórica tem como pressupostos uma série de julgamentos de valor, ou seja, de escolhas por princípios éticos e teóricos. O primeiro deles é o de que a desigualdade tem uma origem de ordem material e não de ordem natural. Daí decorre que a desigualdade pode ser sistemicamente estruturada, no lugar de ser determinada pela sorte. Por último, na distribuição de recursos, as necessidades coletivas podem sobrepor-se às demandas individuais (SMITH, 1989: 148). 
Para Marshall não há um princípio universal que determine quais direitos e deveres serão delegados aos cidadãos, já que a cidadania é uma instituição de desenvolvimento desigual de país para país. Cada sociedade cria uma imagem de uma cidadania ideal que serve como referência e medida das realizações sociais nesse sentido.

A cidadania requer, em sua opinião,

um senso direto de membro da comunidade baseado na lealdade a uma civilização que é possessão comum. É uma lealdade de homens livres outorgada com direitos e protegida por uma lei comum. Seu crescimento é estimulado tanto pela luta para ganhar aqueles direitos quanto pelo seu desfrute quando ganhos. (apud STEWART, 1995: 68)

Na opinião de Turner (apud STEWART, 1995: 69), Marshall contribuiu decisivamente para aumentar a compreensão das mudanças que se operam nas relações entre um status legalmente definido - no caso, o de cidadão - e outras dimensões das relações sociais, especialmente a desigualdade de classes. Stewart (1995: 70), por outro lado, valoriza a maneira como a obra de Marshall ilumina a percepção de concepções diferenciadas de cidadania, a partir da apresentação de um paradoxo, ao demonstrar que a cidadania enquanto status universal é incompatível com a sociedade de mercado e, ao mesmo tempo, co-existia com ela até aquele momento.

Para Marshall, este aparente paradoxo se explicava pelo fato de que, naquele estágio, o núcleo da cidadania se compunha dos direitos civis, direitos estes que se constituíam em "parte indispensável de uma economia competitiva de mercado". Para ele, tais direitos adequavam-se ao engajamento individual na luta econômica dispensando a proteção social. Na prática, portanto, a pregada igualdade perante a lei enfrentaria obstáculos que constrangeriam a existência de uma plena cidadania. Marshall identificava dois tipos de obstáculos: os de ordem subjetiva, ligados ao preconceito de classe, e os de ordem objetiva, expressos na própria desigualdade material, de bens e recursos.

Stewart (1995: 70) chama a atenção para a distinção, presente no pensamento de Marshall, entre uma cidadania individualista e formal de direitos naturais e a cidadania social - objeto central de sua preocupação - fruto da intervenção estatal sobre a desigualdade social.

A finalidade primordial de sua teoria foi a de amenizar ou procurar corrigir as desigualdades que o capitalismo e a sociedade de classes produzem incessantemente. E isto seria uma responsabilidade de toda a comunidade e do Estado, sob pena de convivermos progressivamente com a injustiça social (MARSHALL, 1992: 36). Acreditava que a cidadania social tenderia a reduzir desigualdades sociais, especialmente aquelas ligadas às operações de mercado já que a administração pública de bens e serviços entendidos como direitos interferiria no valor de mercado atribuído a cada indivíduo (cf. BARBALET, 1993: 38). 
Tal modelo de cidadania, difundido a partir dos países capitalistas centrais, traduziu-se, mais especificamente, no chamado Estado do Bem-estar Social (Welfare State). E o nexo político da cidadania com o território passou a se dar fundamentalmente através das políticas públicas que visavam corrigir desigualdades do sistema econômico e dar vazão a reivindicações sociais específicas.Tais aspirações animaram os movimentos sociais urbanos de cunho reformista nos anos 60 e 70 e foram expressas no debate da chamada questão urbana. O colapso do Estado do Bem-estar Social na década de 80, extinguindo ou abalando fortemente direitos sociais já adquiridos, é um dos componentes da atual crise da cidadania no mundo.

Assiste-se, então, nesse momento, a uma dupla reação em relação ao pensamento de Marshall. De um lado, ele é revalorizado como referência para que se (re)pense novos patamares de cidadania sobre uma base de princípios que se contraponham à aceleração da desigualdade, ratificada pela ideologia neoliberal - ou neo-conservadora, como demonstram os teóricos social-democratas. De outro lado, os mesmos pensadores que voltam às formulações de Marshall procuram compreender mais profundamente seus limites, fazendo a crítica necessária para sua superação ${ }^{1}$.

Giddens (1982, apud Stewart, 1995: 69), por exemplo, critica o apoio na "mão beneficente do Estado" como alavanca para um desenvolvimento evolucionista da cidadania. Turner (1987, apud Stewart, 1995: 69) assinala que Marshall negligencia a problemática que envolve as relações entre a noção de cidadania nacional e a constituição do Estado-nação. Stewart (1995: 70) identifica o principal limite de

\footnotetext{
${ }^{1}$ A sociologia inglesa, sobretudo, tem se ocupado da revisão do pensamento de Marshall. A esse respeito, ver principalmente Bottomore, T. Citizenship and social class, Londres: Pluto Press, 1992; Giddens, A. "Class division, class conflict and citizenship rights" in Profiles and critiques in social theory, Londres: Macmillan, 1982; King, D.S. e Waldron, J. "Citizenship, social citizenship and the defense of welfare provision", British Journal of Political Science, 18: 415-43, 1988; Mann, M. "Ruling class strategies and citizenship", Sociology, 21: 339-54, 1987; Oldfield, A. "Citizenship: an unnatural practice?", Political quarterly, 61 (2): 177-87, 1990; Oldfield, A. Citizenship and community, Londres: Routledge, 1990; Roche, M. Rethinking citizenship: welfare, ideology and change in modern society, Oxford: Polity Press, 1992; Turner, B.S. Citizenship and capitalism: the debate over reformism, Londres: Allen and Unwin, 1986; Turner, B.S. "Outline of a theory of citizenship", Sociology 24: 189-217, 1990. Alguns desses artigos foram republicados ao lado de outros em coletâneas, dentre as quais destacamos: Bulmer, M. e Rees, A. M. (ed.) Citizenship today: the contemporary relevance of T.H.Marshall, Londres: UCL Press, 1996; Mouffe, C. (ed.) Dimensions os radical democracy: pluralism, citizenship, community, Londres/New York: Verso, 1992; Steenbergen, B. van (ed.). The condition of citizenship, Londres/Thousand Oaks/New Delhi: Sage, 1994; Turner, B.S. (ed.), Citizenship and social theory, Londres/Thousand Oaks/New Delhi: Sage, 1993. Na sociologia francesa, tem-se destacado, neste debate, Jean Leca, cujos artigos compõem diversas coletâneas inglesas. Destacam-se "Individualisme et citoyenneté", in Sur l'individualisme, Paris: Presses de la Fondation Nationale des Sciences Politiques, 1986, p. 159-209 (republicado em Turner, B.S. e Hamilton, P. Citizenship: critical concepts v. 1, Londres/New York: Routledge, 1994, p. 148-187); "Questions of citizenship", in Mouffe, op. cit., p. 17-32.
} 
Marshall na maneira como situa a cidadania social como uma espécie de complementação da cidadania civil, menosprezando a contradição entre as duas e estabelecendo um contínuo que levaria de uma a outra.

Stewart (1995: 70-71) procura demonstrar que tal idéia de complementaridade canalizou para os mecanismos centralizados no Estado a realização de uma cidadania social. Esta resultaria do atendimento às reivindicações dos cidadãos por direitos que se traduziriam em serviços legalmente oferecidos pelas instituições estatais. Com isso, Marshall deixou de perceber a possibilidade de tensão que se instalaria entre uma versão da cidadania enquanto direitos de bem-estar e uma concepção de cidadania como emancipação e autonomia. A institucionalização da cidadania teria provocado, então, segundo Stewart, a indistinção entre o cidadão e o cliente e acarretado um duplo perigo: a "de-moralização" e a "de-politização".

Uma outra vertente de crítica da teoria de Marshall pode ser encontrada nos teóricos marxistas. Macpherson (1993: 265), discutindo o "futuro provável do conceito de justiça econômica" levanta aspectos do pensamento de Marx que podem contribuir para se pensar os limites da cidadania na sociedade capitalista. Em seu texto Crítica do Programa de Gotha, o filósofo mais radical do século XIX condena a lógica social-democrata da época que reivindicava uma distribuição eqüitativa do produto social. No seu entender, esse modo de pensar desvinculava a esfera da circulação das relações de produção. Se era justo "buscar aumentar o quinhão dos trabalhadores à custa dos capitalistas", não se devia alimentar a ilusão de uma distribuição realmente eqüitativa (1993: 272-273).

Jon Elster (1993), num artigo sobre a exploração, apóia-se sobre o mesmo texto de Marx para considerar o princípio de contribuição e o princípio das necessidades e pensar a possibilidade de distribuição de bem-estar de forma eqüitativa. Nessa linha, assinala um pressuposto básico do pensamento de Marx referente ao Estado, vinculando a igualdade à satisfação no reino das necessidades e da liberdade, com o fim do próprio Estado.

Portanto, na perspectiva marxista não há cidadania possível sem uma ruptura da sociedade em relação ao Estado capitalista. Numa interpretação radical, o debate sobre a cidadania não tomaria o centro das atenções. Por outro lado, pode-se perceber que estes fundamentos marxistas fornecem argumentos para o debate que se trava, hoje, em torno dos limites do pensamento de Marshall.

\section{Conclusão}

Como a cidadania é, sobretudo, uma questão de poder, os contornos de sua efetivação se delineiam sob a pressão de interesses diversos que procuram encontrar espaço de expressão e negociação. Consideramos a cidade um campo de observação privilegiado para pensarmos os rumos que toma hoje a construção prática e teórica da cidadania, assim como seus efeitos. 
Entendemos cidadania como uma dada condição humana - de consciência politica e social - que traz em si um ideal de bem-estar e felicidade que tem variado historicamente, de acordo com a diversidade das culturas. Como elementos desta condição temos: a participação e o nível de consciência política, o grau de igualdade ou eqüidade, o grau de liberdade, o nível de garantia de um conjunto de direitos, o grau de acessibilidade a bens, serviços e equipamentos sociais.

O cidadão é, então, o indivíduo normatizado, ou seja, vivendo sob normas, conformadas pelo desenvolvimento material e cultural da sociedade a que pertence, acordadas por um contrato social (estatuto de direitos e deveres) e ajuizadas e reguladas pelo Estado. Portanto, a cidadania depende da condição material e cultural que possui um indivíduo, concebida como herança histórica, da posição social que ele ocupa na sociedade em questão e do nível de participação nas decisões que definem os seus rumos nas diferentes escalas social e geográfica, da comunidade local ao poder do Estado nacional.

O acompanhamento do debate recente, que retoma, ao mesmo tempo em que propõe a revisão, dos autores clássicos da filosofia política, levou-nos a sistematizar em seis aspectos as diversas dimensões da cidadania.

A primeira delas é a dimensão natural, aquela que está na base da Declaração Universal dos Direitos do Homem e do Cidadão. Ela sintetiza o universalismo iluminista que deseja a igualdade de todos os homens, justificada pelo pertencimento à espécie. Esta dimensão fornece os fundamentos para os direitos civis - liberdade de expressão e manifestação, o direito de ir e vir, etc..

A segunda é a dimensão política, presente historicamente, desde a polis grega, mas ampliada na modernidade pela construção do Estado burguês. Como o próprio nome indica, diz respeito aos direitos políticos, que implicam participação direta ou representatividade nas instâncias de decisão. O direito de voto, de ser eleito, etc. encontram-se neste âmbito.

A terceira dimensão é sócio-econômica e abarca as condições que permitem, em última instância, a própria manutenção da vida e a capacidade de pensar, decidir e influir nos destinos da coletividade, seja a nível micro ou macro, chegando ao âmbito mundial. Essa foi a dimensão incorporada por Marshall ao propor a idéia de direitos sociais.

A quarta dimensão - bem como as seguintes - não encontra equivalência direta num conjunto de direitos, mas, como demonstramos no início deste texto, não se pode pensar a cidadania sem incorporá-la. Trata-se da dimensão geográfica, que associa território e cultura e que sedimenta e materializa as condições de realização da cidadania.

A quinta decorre, em parte, da quarta dimensão. É a dimensão cívica, que pressupõe o estabelecimento de regras de convivência enquadradas nos padrões culturais de cada contexto histórico. Embora ligada aos direitos civis e, ao mesmo tempo, à cultura, expressa-se, sobretudo, como deveres que, na origem, seriam a expressão dos limites impostos pela existência e o respeito ao "outro". 
A sexta e última dimensão é a mais impalpável, mas tem sido cada vez mais valorizada num mundo em que a exacerbação do individualismo, associada do marketing, da midia e da informática aumentam o isolamento e esgarçam os laços de sociabilidade. Referimo-nos aqui à noção de pertencimento, sem a qual cessam as motivações para a preservação de qualquer cidadania.

As encruzilhadas com que se depara a teoria da cidadania, assim como os dilemas postos pela conjuntura atual às alternativas de se efetivar uma cidadania referenciada pelos marcos da democracia, geram, a nosso ver, a necessidade de que se multipliquem estudos voltados para a questão. É preciso, sobretudo, acompanhar como se formulam e se implementam políticas que afetam, direta ou indiretamente, a realização da cidadania. Por outro lado, cabe observar como tais políticas, orientadas por diretrizes do momento, se combinam com aspectos tradicionais, históricos, específicos do processo de construção de patamares de cidadania em cada lugar.

\section{UM CONCEITO DE CIDADANIA PARA SE TRABALHAR A CIDADE}

Resumo: O tema da cidadania é um dos mais caros e necessários no pensar e agir urbano. Intrinsecamente ligada à geograficidade na história, a cidadania vem sendo matéria de reflexão desde o pensamento clássico com Aristóteles, ganhando centralidade no atual contexto de um espaço global.

Palavras-chave: Cidadania, Cidade, Política.

\section{A CONCEPTION OF CITIZENSHIP TO STUDY THE CITY}

Summary: Citizenship is one of the most relevant and necessary issues to think and for the action on the urban space. Intrinsically linked with the geographicity in history, the citizenship has been subject of reflexion since the classical thought with Aristotle, receiveing a central place in the actual period of globalization.

Keywords: Citizenship, City, Politics.

\section{BIBLIOGRAFIA}

ARENDT, H.(1998): O que é política. Rio de Janeiro: Bertrand Brasil. ARISTÓTELES. (1991): A Política. São Paulo: Martins Fontes. AUGUSTIN, S. (1994): La Cité de Dieu. Paris: Seuil (vol. 1). BARBALET, J. M. (1993): Citizenship, class inequality and resentment. In: TURNER, Bryan S. Citizenship and social theory. Londres/Thousand Oaks/New Delhi: Sage.

BOBBIO, N. (1990): Dicionário de política. Rio de Janeiro.

CLARKE, P.B. (1994): Citizenship. Londres/Boulder: Pluto Press. DEFOURNY, M. (1932): Aristote. Étude sur la politique. Paris, s.ed. DUBY, G. (1990): O Tempo das Catedrais. Lisboa, Editorial Presença. DUMONT, L. (1993): O Individualismo. Uma Perspectiva Antropológica da Ideologia Moderna. Rio de Janeiro, Rocco. 
ELIAS, N. (1987): A Sociedade de Corte. Lisboa, Editorial Estampa. . O Processo Civilizador. Rio de Janeiro, Jorge Zahar, 1993. (2º Vol.)

ELSTER, J. (1993): Exploração, liberdade e justiça. In: KRISCHKE, Paulo J. (org.). O contrato social: ontem e hoje. São Paulo: Cortez.

GIDDENS, A. (1982): "Class division, class conflict and citizenship rights" in Profiles and critiques in social theory, London: Macmillan.

GLOTZ, G. La cité grecque. Paris, s.ed., 1928.

GRUPPI, L. (1980): Tudo Começou com Maquiavel. Porto Alegre, L\&PM.

HAROUEL, JL. (1990): História do Urbanismo. Campinas, Papirus.

HOBBES, T. (1992): Do Cidadão. São Paulo: Martins Fontes.

. Leviatã. São Paulo: Abril Cultural, 1974. (Coleção Os Pensadores)

LECA, J. (1991): Individualisme et citoyenneté. In: BIRNBAUM, Pierre \& LECA, Jean (dir.). Sur L'Individualisme. $2^{\mathrm{a}}$ ed., Paris: Presses de la Fondation Nationale des Sciences Politiques, p. 159-209.

Questions of citizenship, In: MOUFFE, Chantal (ed.) Dimensions os radical democracy: pluralism, citizenship, community, Londres/New York: Verso, 1992, p. 17-32.

LEFEBVRE, H. (1978): El derecho a la ciudad. 4a. ed., Barcelona: Península.

LE GOFF, J. (1983): A Civilização do Ocidente Medieval. Lisboa, Editorial Estampa.

O Homem Medieval. Lisboa, Presenção, 1990.

LÉVY, J. (1994): L'espace légitime: sur la dimension géographique de la fonction politique. Paris: Presses de la Fondation Nationale des Sciences Politiques.

LOCHAK, D. (1992): Qu'est-ce qu'un citoyen? Raison Présente: Le citoyen, l'Europe, le monde, Paris, 103: 11-26.

MACPHERSON, C.B. (1993): Ascensão e queda da justiça econômica. In: KRISCHKE, Paulo J. (org.). O contrato social: ontem e hoje. São Paulo: Cortez.

MARSHALL, T. H. (1992): Citizenship and social class. Londres: Pluto Press, 1950. $2^{\text {a }}$.ed.)

MARX, K. (1982): A questão judaica. Rio de Janeiro: Achiamé.

MUMFORD, L. (1965): A Cidade na história. Belo Horizonte, Itatiaia, (2º Vol.)

ROUSSEAU, JJ. Do contrato social. São Paulo: Abril Cultural, 1973. (Coleção Os Pensadores, v. XXIV)

SANTOS, M. (1987): O espaço do cidadão. São Paulo: Nobel.

SENNETT, R. (1993): O declínio do homem público. As Tiranias da Intimidade. 3a. ed., São Paulo: Companhia das Letras.

. Carne e pedra. O corpo e a cidade na civilização ocidental. Rio de Janeiro: Record, 1997.

SMITH, S. Society, space and citizenship: a human geography for the "new times'? Transations, Londres, Institute of British Geographers, 14 (2): 144$156,1989$. 
STEWART, A. (1995): Two conceptions of citizenship. British Journal of Sociology, Londres, 46 (1): 63-78, março.

TOURAINE, A. (1995): La formation du sujet. In: TOURAINE, A. (dir.). Penser le sujet. Paris: Fayard.

TURNER, B. S. (ed.). (1993): Citizenship and social theory. $2^{\mathrm{a}}$ ed., London/Thousand Oaks/ New Delhi: Sage.

TURNER e HAMILTON, P (ed.). (1994): Citizenship: critical concepts v. 1. Londres/New York: Routledge.

WEBER, M. (1947): La ville. 3a. ed., Paris: Aubier Montaigne.

WENDEN, CW de. (1992): Question de citoyenneté. Espaces et societés: Urbanité et citoyenneté, Paris: L'Harmattan, 68: 37-45. 